\title{
Studies on biosimilar medications
}

\section{Estudos de medicamentos biosimilares}

\author{
Winston Bonetti Yoshida*
}

\begin{abstract}
In Brazil, the registration of new drugs is carried out only when the regulatory agency (Anvisa, acronym in Portuguese) is fully satisfied with the evidence of their quality, efficacy and safety, presented by a pharmaceutical industry that strive for this registration. With the patent expiration, pharmaceutical companies are attracted to produce biological medicines called biosimilar or biogenerics or simply generics, whose approval may result in reduced treatment costs. But it is necessary that the biosimilar be, at least, equally effective and safe and without contaminants in relation to the original. Recent consensus guidelines aim to establish criteria for efficacy and safety of these medicines. Preclinical studies in vitro and in vivo, the origin of raw materials and clinical studies phase I, II and III are recommended for biosimilar medicine registration in the international market. Low molecular weight heparins are found in this situation. In this review we specifically addressed this type of medicine, which could serve as a benchmark for other biosimilar medicines.
\end{abstract}

Keywords: Heparin; heparin, low-molecular-weight; drugs, generic; practice guidelines as topic; therapeutic equivalence

\section{Resumo}

No Brasil, o registro de novos medicamentos é feito apenas quando a agência reguladora - Agência Nacional de Vigilância Sanitária (Anvisa) - se satisfaz plenamente com as evidências de sua qualidade, eficácia e segurança, apresentadas por uma indústria farmacêutica que pleiteie esse registro. Com o vencimento de patentes, empresas farmacêuticas se sentem atraídas pela produção medicamentos biológicos chamados de biosimilares ou biogenéricos ou simplesmente genéricos, cuja aprovação pode resultar em redução de custos de tratamento. Mas é preciso que o biosimilar seja, pelo menos, igualmente eficaz e seguro e sem contaminantes em relação ao original. Consensos recentes apontam diretrizes para estabelecer critérios de eficácia e segurança desses medicamentos. Estudos pré-clínicos in vitro e in vivo, procedência da matéria-prima e estudos clínicos fase I, II e III são preconizados para registro do produto biosimilar no mercado internacional. As heparinas de baixo peso molecular encontram-se nessa situação. Nesta revisão, abordamos especificamente esse tipo de medicamento, o que pode servir de parâmetro para outros biosimilares.

Palavras-chave: Heparina; heparina de baixo peso molecular; medicamentos genéricos; guias de prática clínica como assunto; equivalência terapêutica.

\section{Introduction}

In Brazil, new drugs registration is only done when the regulatory agency - Agência Nacional de Vigilância Sanitária (Anvisa) - is completely satisfied with the evidence of their quality, efficacy and safety presented by a pharmaceutical industry that applied for the registration ${ }^{1}$. The efficacy evidence is generally obtained by means of controlled clinical trials, in which a group of patients is given the new medication and another group (referred to as the control group) takes placebo or the habitual or gold-standard treatment. The design of the study must be randomized and preferentially double-blind, as the investigators and the patients do not know what they are taking until the study is concluded. When one of the groups is given more than one drug, it is interesting that their placebos (oral or injectable) be prescribed for both groups, so the concealment of the treatment is assured. This technique is referred to as double-dummy. These studies, known as phase III studies, are only conducted after the conclusion of preliminary research, known as phase-I and phase-II studies, which involve a relatively small number of healthy or ill patients ${ }^{1}$. From the conception of a new molecule until the phase III, in general, there are ten years of research and development on average, with costs accounting for US\$ 350 million.

Department of Surgery and Orthopedics of the Medical School of Universidade Estadual Paulista "Júlio de Mesquita Filho" (UNESP), Botucatu, SP.

* Adjunct Professor; Post-doctorate degree; Professor at the Department of Surgery and Orthopedics of the Medical School of Universidade Estadual Paulista "Júlio de Mesquita Filho" (UN-

ESP), Botucatu, SP.

Conflict of interest: member of the Advisor Group of Bayer-Schering Pharma Brazil.

Received on May 12, 2010. Accepted on May 31, 2010

J Vasc Bras. 2010;9(2):141-144. 
Biological medications, referred to as biosimilars, biogenerics or simply generics, have different meanings according to the regulatory agencies. With the expiration of patents, pharmaceutical companies produce copies which approval may result in treatment cost reduction ${ }^{2}$. But the biosimilar should be at least as effective and safe as the original medication, besides not having contaminant agents. Slight biochemical and biological differences may bring significant clinical consequences ${ }^{2}$. In the field of Angiology and Vascular Surgery, the low-molecular-weight heparins (LMWH) are currently in this situation. Recommendations for tests that assure such better characteristics of the biosimilars have been published ${ }^{2}$. This kind of medication will be featured in this review, and may serve as parameter for other biosimilars.

The main concern is the origin of the raw material for the production of heparin, and features such as type of tissue and animal and country where it has been manufactured must be displayed as general information ${ }^{2}$. There are reports of heparin contamination with oversulfated dermatan sulfate that reflected on the entire production of heparins and derived products around the globe and have caused deaths ${ }^{3,4}$ in several countries, including Brazil ${ }^{5}$. In a comparative study on heparins in the Brazilian market, there were some samples contaminated by oversulfated dermatan sulfate, and, even those which were not, did not present the same chemical purity pattern and high specific anticoagulant activity as those of the standard product (Liquemine Roche $)^{6}$. Up to $3 \%$ of natural dermatan sulfate is allowed in the product, but no other glycosaminoglycans or impurities are acceptable ${ }^{2}$.

Comparative studies on structural integrity by magnetic resonance imaging technique ${ }^{7}$, molecular weight assessment ${ }^{8}$ by Sephacryl S-400 gel filtration, and anticoagulant potential by anti-Xa, anti-IIa activities, among others, may point out the similarity and purity between different preparations ${ }^{6}$. The biosimilar's information regarding these aspects must also be displayed on the original product's monograph, over and above the variations between shares must be similar to that of the original product ${ }^{2}$. Besides, analyses on internal disaccharide sequences and terminal 2,5-anhydro-D-mannose residues by the method of nitrous acid degradation, as well as 1,6-anhydro glucose or N-sulfated glucosamine by heparin treatment method, are equally important. The content of sulfate and carboxyl groups must be described based on measures of conductivity and potenciometric titration ${ }^{2}$. Low-molecular-weight heparins (LMWH) contain 12$20 \%$ of antithrombin-binding chains, and this regard may be compared by AT affinity chromatographic techniques, as well as heparin cofactor II activity ${ }^{2}$.

In-vitro tests on the biosimilar's activity must be repeated and coincide with those of the original ${ }^{2}$. Usually, the inhibition of the factors Xa, IIa and aPTT (activated partial thromboplastin time) are employed for this purpose $^{9}$. LMWHs may interact with platelet factor 4 and generate antibodies that stimulate heparin-induced thrombocytopenia (HIT), which presents important clinical implications. These ligations may be quantified by appropriate in-vitro tests ${ }^{10}$. The protamine's capacity of neutralization must also be assessed in comparison with the original product ${ }^{2}$.

Studies on acute and chronic toxicity in at least two animal species in accordance with good laboratory practice guidelines must also be part of the preclinical evaluations, comparing different dosages of the biosimilar and of the originator product. The anticoagulant potential must be gauged using standardized experimental animal models with deep venous thrombosis (DVT) and arterial thrombosis ${ }^{11-14}$

The phase I evaluations in normal volunteers for five to seven days should always be performed. The doses must be conventional for the prevention of venous thromboembolism (VTE), as well as the determinations of aPTT, anti-Xa and anti-IIa activity must be obtained and tests to investigate HIT must be conducted. Subsequent investigations in patients with renal failure must guide dosage schemes in this situation ${ }^{15}$.

At least one double-blind phase III study aiming at prevention of arterial or venous thromboembolism is recommended by the European Medicine Agencies (EMEA). For each situation, at least one study of this type would be necessary, namely VTE prevention in risk situations, DVT and pulmonary embolism treatment, and prevention of coronary events in patients with unstable angina ${ }^{2}$.

On phase III, the biosimilar may be assessed in relation to the original product by statistical studies such as superiority, equivalence and non-inferiority trials (Figure 1). Non-inferiority trials are commonly conducted to compare them. Such study intends to determine whether the similar is at least as effective as the original, or even a little worse, but within a preestablished limit, that is, a variation ${ }^{16}$. If it is better than the original, that is, the results are better beyond this variation, there will be a bonus and the non-inferiority result will be equally suitable. Equivalence studies are more restrict and implicate results that are not better or worse, but rather within the pre-established 


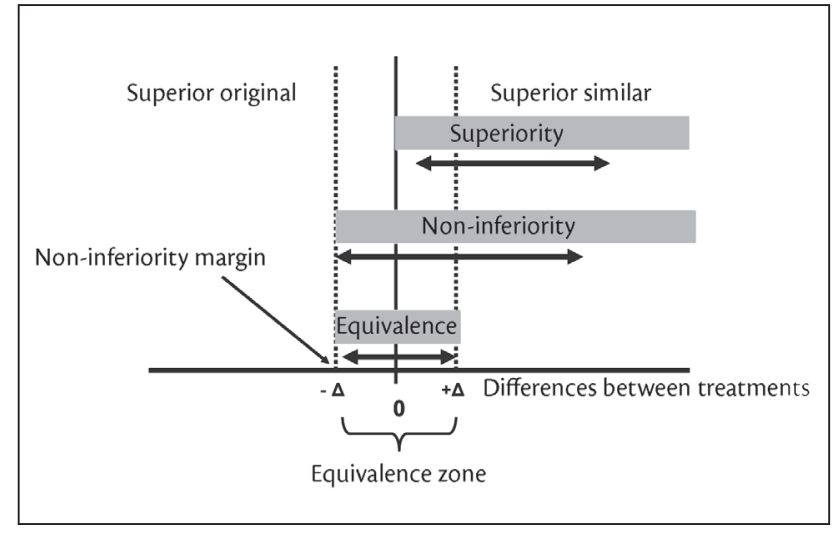

Figure 1 - Confidence intervals comprising the central line do not show significant difference of responses to both treatments. Intervals placed at the right of the central line and do not include it are superior, and those placed at the left are inversely inferior. Confidence intervals placed totally inside the limits of the margins $[-\Delta ;+\Delta]$ are considered equivalent.

variation (Figure 1). The non-inferiority margin $(\Delta)$ is based on previous studies about the originator product, preferentially in comparison to a placebo. Due to ethical implications, this kind of information is rare, and comparisons to products which are considered to be reference are more common. In non-inferiority trials, the studied populations and the outcome must be equal to those of the study which provided the $\Delta$.

The sample size must take into account the level of the confidence interval (generally 95\%), the risk of type II error (incorrect rejection of a non-inferior treatment) or test power and $\Delta$. This margin must be the smallest value presenting an important clinical effect. It is usually variable even in certain studies. There are methods for the calculation of $\Delta^{17}$. The sample size calculation may be done by software similar to that of the Epidemiology and Statistical Laboratory of Universidade de São Paulo (USP), which is available on the internet, among others ${ }^{18}$. Unfortunately, the samples of the equivalence and non-inferiority trials are frequently very small ${ }^{19}$. Moreover, it is necessary to emphasize that eventual withdrawals per group, especially due to failures in the interpretation of exams, must be replaced aiming at the maintenance of the project's statistical power.

Phase III studies must assess the patients who concluded all phases and examinations of the project; they are referred to as per-protocol or on-treatment population. Patients who have taken at least one dose of the treatment, including those who interrupted it by any reason, constitute the intention-to-threat population (ITT), which is essential for evaluating medication safety, because adverse effects may manifest in the beginning of the treatment and be the cause of treatment interruption. Another interesting assessment parameter is the number needed to treat $(\mathrm{NNT})^{20}$. The effects of treatments are better understood by means of this risk measurement, which is the number of patients who need to be treated with the new or concerned treatment to produce a desirable beneficial effect (for instance, headache relief, death or thrombosis prevention etc.) in comparison with a control. It is defined as the inverse of the absolute risk reduction (ARR), that is, facing the risk of a control outcome $\left(p_{\mathrm{B}}\right)$ and experimental treatment $\left(p_{\mathrm{A}}\right)$, the absolute risk is $p_{\mathrm{B}}-p_{\mathrm{A}}$. The NNT is $1 / p_{\mathrm{B}}$ $p_{\mathrm{A}}$. The ideal NNT is 1 , representing the occasion in which all patients respond to the new treatment and nobody gets better with the control. The higher the NNT, the less effective the new treatment $t^{20}$. When the outcome is an adverse effect, calculation is conducted in the same way, but it is referred to as number needed to harm $(\mathrm{NNH})^{21}$.

Another aspect to be emphasized is the way the randomization of groups and the blind assessment is made ${ }^{22}$. It is recommended that, in randomized clinical trials, the process of randomization be done by means of random numbers generated by a computer in order to avoid selection bias. Any other method could be considered technically imperfect. The evaluation of results must also be done by independent examiners without knowledge about the groups, and it is recommended that the agreement between them be investigated by statistical tests ${ }^{22}$.

In conclusion, the tests that are necessary to the registration of biosimilars must follow strict international protocols because of the variability of biological products, particularly LMWHs. Preclinical in-vitro and in-vivo studies clearly showing the pharmacological similarity and purity, as well as pharmacodynamics test in animals, must precede clinical trials. They should always follow the adequate sequence and design in terms of sample size, inclusion and exclusion criteria, outcome similar to that of the original study, sample calculation and non-inferiority margin, randomization, patients' withdrawal and replacement, evaluations of ITT patients ${ }^{16,22}$, and tests in different clinical situations. ANVISA (acronym in Portuguese for the Brazilian Agency of Sanitary Vigilance) has recently organized the III Forum of Biological Medication Update in 2010, and these aspects were addressed and the procedures for approval of this kind of medicines in Brazil were emphasized ${ }^{23}$. To sum up, scientific evidence and safety must always be above any interest other than the patients' well-being. 


\section{References}

1. Brasil. Ministério da Saúde. Agência Nacional de Vigilância Sanitária (Anvisa) [Internet]. Medicamentos. [cited Mar 10, 2010]. http:// portal.anvisa.gov.br/wps/portal/anvisa/home/medicamentos

2. Harenberg J, Kakkar A, Bergqvist D, et al. Recommendations on biosimilar low-molecular-weight heparins. J Thromb Haemost. 2009; 7:1222-5

3. Kishimoto TK, Viswanathan K, Ganguly T, et al. Contaminated heparin associated with adverse clinical events and activation of the contact system. N Engl J Med. 2008;358:2457-67.

4. Nosé Y. Hemodialysis patients' deaths in the USA by contaminant suspected heparin originating from China. Artif Organs. 2008;32:425-6

5. Cavalheiro Filho C, Chamone Dde A, Rached RA, Maffei FH. Heparins - current status. Rev Assoc Med Bras. 2008;54:471-2.

6. Melo El, Pereira MS, Cunha RS, Sá MP, Mourão PA. Heparin quality control in the Brazilian market: implications in the cardiovascular surgery. Rev Bras Cir Cardiovasc. 2008;23:169-74.

7. Guerrini M, Guglieri S, Naggi A, Sasisekharan R, Torri G. Low molecular weight heparins: structural differentiation by bidimensional nuclear magnetic resonance spectroscopy. Semin Thromb Hemost. 2007;33:478-87.

8. Gray E, Mulloy B, Barrowcliffe TW. Heparin and low-molecularweight heparin. Thromb Haemost. 2008;99:807-18.

9. Gray E, Rigsby P, Behr-Gross ME. Collaborative study to establish the Low-molecular-mass heparin for assay--European Pharmacopoeia Biological Reference Preparation. Pharmeuropa Bio. 2004;2004:59-76.

10. Fareed J, Bick R; International Academy of Clinical and Applied Thrombosis Hemostasis and Vascular Medicine. Differentiation of low-molecular-weight heparins: practical implications. Clin Appl Thromb Hemost. 2004;10:299-300.

11. Maffei FH, Pinto AM, Fabris VE, Lastória S, Rollo HD. Experimental venous thrombosis in guinea pigs: effect of heparin and drugs affecting platelet function (author's transl). Rev Bras Pesqui Med Biol. 1977;10:369-78.

12. Maffei FH, Rollo HA, Fabris VE. Prevention of experimental venous thrombosis induced by contrast medium in the rat. Acta Radiol Diagn (Stockh). 1980;21:249-52.
13. Lastória S, Thomazini IA, Cury PR, Maffei FH. Platelet activation in experimental arterial thrombosis. Braz J Med Biol Res. 1987;20:611-3.

14. Yoshida WB, Maffei FH, Lastória S, Curi PR, Rollo HA. Lumbar sympathectomy and distal arteriovenous fistula as adjuncts to prevent arterial rethrombosis after thrombectomy: experimental study in dogs. J Cardiovasc Surg (Torino). 1988;29:19-25.

15. Lim W, Dentali F, Eikelboom JW, Crowther MA. Meta-analysis: lowmolecular-weight heparin and bleeding in patients with severe renal insufficiency. Ann Intern Med. 2006;144:673-84.

16. Piaggio G, Elbourne DR, Altman DG, Pocock SJ, Evans SJ; CONSORT Group. Reporting of noninferiority and equivalence randomized trials: an extension of the CONSORT statement. JAMA. 2006;295:1152-60.

17. Rothmann MD, Tsou HH. On non-inferiority analysis based on delta-method confidence intervals. J Biopharm Stat. 2003;13:565-83.

18. Laboratório de Epidemiologia e Estatística [Internet]. Comparação de duas proporções. [cited Aug 16, 2010]. http://www.lee.dante. br/pesquisa/amostragem/di_2_pro.html

19. D’Agostino RB Sr, Massaro JM, Sullivan LM. Non-inferiority trials: design concepts and issues - the encounters of academic consultants in statistics. Stat Med. 2003;22:169-86.

20. Halvorsen PA, Selmer R, Kristiansen IS. Different ways to describe the benefits of risk-reducing treatments: a randomized trial. Ann Intern Med. 2007;146:848-56.

21. McQuay HJ, Moore RA. Using numerical results from systematic reviews in clinical practice. Ann Intern Med. 1997;126:712-20.

22. Jüni $P$, Witschi $A$, Bloch $R$, Egger $M$. The hazards of scoring the quality of clinical trials for meta-analysis. JAMA. 1999;282:1054-60.

23. Pinto V. Seminário sobre Estudos de Não-Inferioridade. III Fórum de atualização em medicamentos biológicos; 2010 Fev 26; Brasília: Anvisa; 2010

Correspondence: Winston Bonetti Yoshida

Departamento de Cirurgia e Ortopedia da Faculdade de Medicina de Botucatu da UNESP CEP 18618-970 - Botucatu, SP E-mail:winston@fmb.unesp.br 